
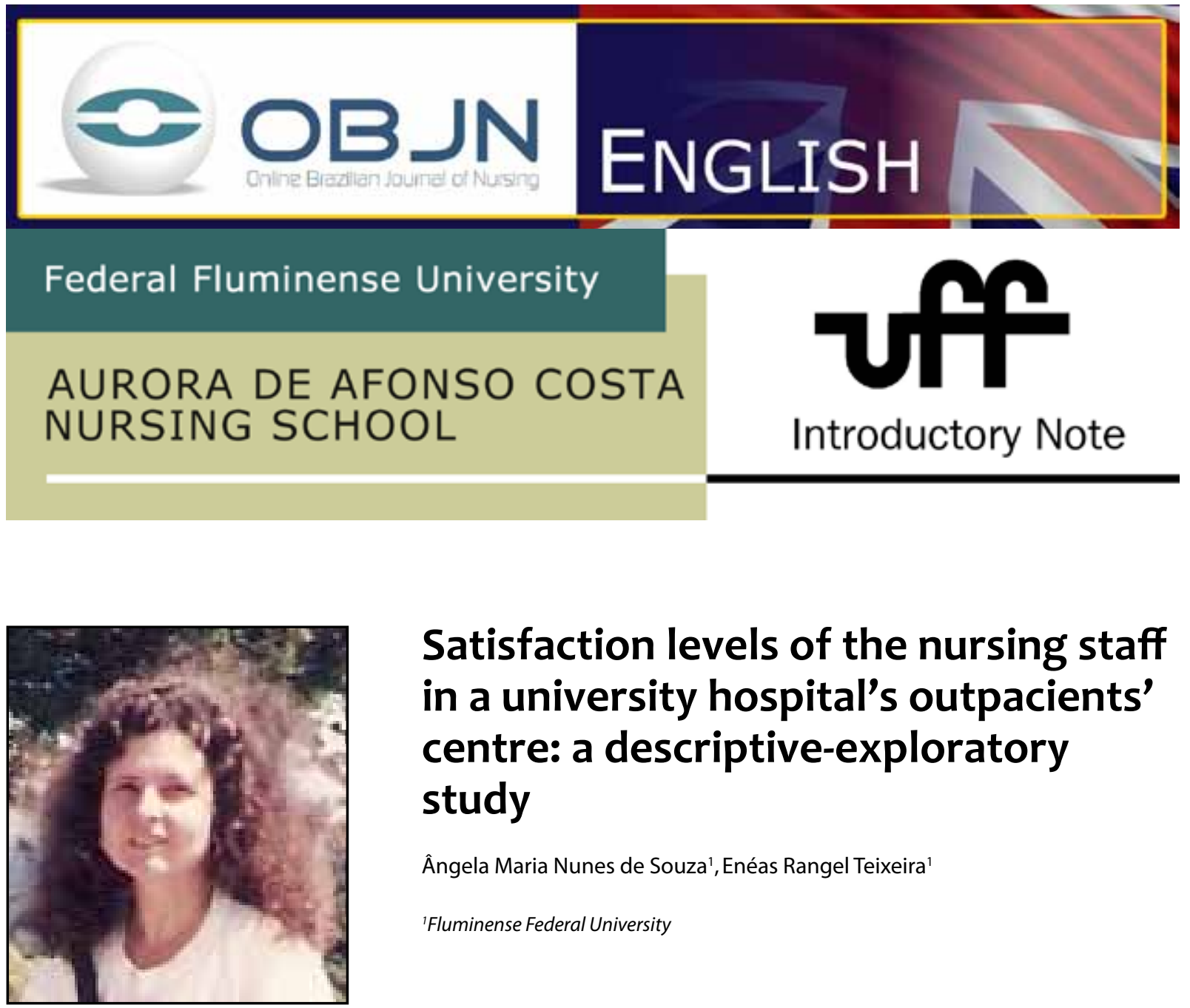

\title{
Satisfaction levels of the nursing staff in a university hospital's outpacients' centre: a descriptive-exploratory study
}

Ângela Maria Nunes de Souza', Enéas Rangel Teixeira ${ }^{1}$

${ }^{1}$ Fluminense Federal University

\section{ABSTRACT}

This is a dissertation research project of the Social Care Master's Program at the Fluminense Federal University (UFF). It is based on a humanizing perspective of social care that aims to improve the workers'job satisfaction. Aims: to identify the motivational resources used by the nursing staff to perform their tasks; to discuss the conceptions of satisfaction held by the nursing staff; to propose the development of a technology in care for the nursing staff so as to promote wellbeing within the workplace.

Method: this is a descriptive- exploratory study using a qualitative approach.

Expected results: It is anticipated that relevant data will be collected and will enable the development of technologies to both humanize and improve staff management so as to contribute to the humanization of healthcare, satisfaction in the workplace, and also professional satisfaction.

Descriptors: Occupational Health; Working Conditions; Job Satisfaction; Nursing. 


\section{RESEARCH PROBLEM AND ITS SIGNIFICANCE}

Working in nursing care not only enables the professional to provide care to patients and to deal with several health situations, but also to have an income. The nursing practice can be a source of personal satisfaction, but also can be exhausting both physically and mentally. If the professionals do not use any kind of support strategies, they might become ill and feel dissatisfied with the profession. Satisfaction is a human need and core part of an efficient organization. It is important to prioritize the human and social aspect of any organization over the technical support, such as equipments and rules with functions and procedures ${ }^{(1)}$.

To realize the purpose of a job can have effects upon the organization of the work process, on the quality of the service provided and on the workers' health. To understand the purpose of a job enables the managers to develop strategies to promote the workers' health, which will improve the quality of the service and job satisfaction ${ }^{(2)}$.

So, working becomes a bridge, if not the only one, between subconscious and social field and also between social and collective order. Working is not only a subjective investment, but also a space for construction of meaning, and therefore the subjects' identity, continuity and personal story ${ }^{(3)}$.

\section{GUIDING QUESTION}

This study intends to investigate the satisfaction levels of the nursing staff in an outpacients' centre at a university hospital and proposes the following questions: What is the conception of satisfaction held by the nursing staff? What should be done to improve moti- vation and job satisfaction levels among the nursing staff?

\section{AIMS}

To identify the motivational resources used by the nursing staff to perform their tasks; to discuss the conceptions of satisfaction held by the nursing staff; to propose the development of a technology in care addressed to the nursing staff so as to promote wellbeing within the workplace.

\section{ASSUMPTIONS}

It is anticipated that there is a relationship between job satisfaction and the assistance delivered; job satisfaction can have effects upon the quality of the service provided; and that the development of new technologies in care within the workplace can be a motivational source to help improve job satisfaction.

\section{METHOD}

In October 2012, the development of this study began with an integrative review of the related literature at LILACS e MEDLINE, seeking information from 2006 to 2012. To do so, the following descriptors were used: worker's health/ working conditions/ job satisfaction/ nursing. This timeframe is due to the Health Pacts of 2006, established by the Directives and Recommendations to the Integral Health Care, in which the Ministry of Health points to some strategic areas, among which is the'worker's health'. This is a descriptive- exploratory study using a qualitative approach. The research setting will be the outpatients' center of the Antonio Pedro Univer- 
sity Hospital (HUAP) in Niterói, Rio de Janeiro. The data collection will be undertaken through semi-structured interviews and field observation from July to September, 2013. Participants include members of the nursing staff (nurses, technical nurses and nursing assistants) of the hospital. The inclusion criterion is: professionals who have worked for more than three years in the sector. The exclusion criterion is: professionals who are away from the activities performed in the outpatients' centre. The interviews will be transcribed, and the information collected during the field observation will be registered in a recording sheet. Then, the final text will be carefully read and categorized in order to meet the aims and assumptions of the study. After this phase, all information will be analyzed through the discourse analysis method.

\section{EXPECTED RESULTS}

From the study's results, it is anticipated that the context of the nursing work will be better understood and that it will enable the development of technologies that will be applied in workshops. During the workshops the workers will have the opportunity to share the problems and issues faced in their practice with the aim to come up with communal solutions with the manager of the institution. In this way, it is expected that a deeper understanding of the work context will be achieved as well as promoting the development of resources to fight adverse conditions and thus boosting the workers' self-esteem and job satisfaction levels. Consequently, it will cause an improvement in the assistance delivered to patients in the health institution.

\section{REFERENCES}

1. Oliveira SL. Sociologia das organizações: uma análise do homem e das empresas no ambiente competitivo. 6. ed. São Paulo: Cengage Learning; 2009.

2. Dejours C, Abdoucdeli E, Jayet C. Psicodinâmica do trabalho: contribuições da escola Dejouriana à análise da relação prazer, sofrimento e trabalho. São Paulo: Atlas; 2009.

3. Silva RM, Beck CLC, Zeitoune RCG, Prestes FC, Tavares JP, Guerra ST. Meaning of work for night nurses of a university hospital: descriptive study. Online braz j nurs [Internet]. 2011 Dec [Cited 2013 Sept 8]; 10 (3): [about 4 p.]. Available from: http://www.objnursing.uff.br/index.php/ nursing/article/view/3433. doi: http://dx.doi. org/10.5935/1676-4285.20113433

RESEARCH'S DETAILS

Dissertation Project of the Social Care Master's Program of UFF. This project has been approved by the IRB of UFF, under no. CAAE: 13646813.5.0000.5243

Researcher's Mentor: Enéas Rangel Teixeira

Financial Support: private financial support

Received: $18 / 08 / 2013$

Revised: 07/09/2013

Approved: 09/09/2013 